\title{
Operation Moshtarak and the manufacture of credible, "heroic" warfare
}

Richard Lance Keeble argues that Fleet Street's coverage of the Afghan conflict has served largely to promote the interests of the military/industrial/media complex - and marginalise the views of the public who have consistently appealed in polls for the troops to be brought back home

\section{Introduction}

This chapter examines Fleet Street's coverage of the US-led Operation Moshtarak in Afghanistan in 2010. It outlines the major strands of US/UK military strategy since the 1980s (defined here as New Militarist) and argues that the conflict in Afghanistan, as currently represented in the mainstream media, is no war at all: rather it's a series of manufactured, media-hyped “operations” led by a nation with the largest and most heavily resourced fighting force in history, against a pitifully under-resourced and yet skilful and merciless guerrilla movement in one of the most impoverished countries in the world.

So the role of the media embedded with the military is to manufacture the image of legitimate, heroic “warfare” against a credible threat. In the process the reality of the conflict, the appalling suffering of the Afghan people, is kept secret from the British public. The chapter also considers Fleet Street's editorial stances on the Afghanistan war - which was costing the UK £5billion a year (see Norton-Taylor 2010a) ${ }^{1}$ - and the ways in which the views of the public (most of whom consistently call for the withdrawal of troops from Afghanistan) have been marginalised. The study draws on a range of alternative media to critique mainstream coverage.

\section{Secret warfare}


There are three major strands to New Militarist strategy - each accompanied by a particular form of media coverage. Firstly the most important strategy is conducted in complete secrecy away from the glare of the media. This involves in the case of Afghanistan during 2010:

- the targeted assassinations in both Afghanistan and over the border in Pakistan of alleged Taliban leaders (Walsh 2010a);

- the night raids by the CIA and some of its 56,000 Special Forces, such as the Green Berets and Navy SEALS, Special Boat teams, Air Force Special Tactics Teams and Marine Corps Special Operations Battalions (see Gopal 2010; Turse and Engelhardt 2010; Porter 2010a; Grey 2009a); ${ }^{2}$

- the secret detention and torture centres;

- the secret and massively expensive installation of almost 400 US and coalition military bases in Afghanistan and at least 300 Afghan National Army (ANA) and Afghan National Police (ANP) bases. According to investigative reporter Nick Turse (2010): “Existing in the shadows, rarely reported on and little talked about, this base-building programme is nonetheless staggering in size and scope...It has added significantly to the already long secret list of Pentagon property overseas and raises questions about just how long, after the planned beginning of a drawdown of American forces in 2011, the US will still be garrisoning Afghanistan.”3

- the many disappearances;

- the increasing and largely secret use of pilotless drones to attack targets in Afghanistan and over the border in Pakistan; ${ }^{4}$ In a celebratory feature on Britain’s £124 million drones programme, Rob Waugh (2010) commented: “Autonomous machines save money, save pilots’ lives and point to a future 
where Stealth-enabled unmanned fighters and ultra-long-endurance surveillance planes can almost remove human beings from the aerial battlefield. But this technology has largely appeared without governments or the public questioning it."

- the penetration of allied and enemy governments by the CIA/MI6. In October 2009, for instance, it was revealed that the brother of Afghan president, Ahmed Wali Karzai, long alleged to be a powerful drug lord, had been on the CIA's payroll for almost eight years (Borger 2009). Leaks of this kind reflected the rivalries amongst the US's 16 intelligence agencies (see MacAskill, Nasaw and Boone 2010a;

- $\quad$ and the Pakistan military offensives against the Taliban and al-Qaeda, instigated by Washington, which have claimed thousands of lives and displaced over a million people in the northwestern tribal areas (see Cockburn 2010a, 2010b). In particular, there are the little reported attacks by the army against the rising independence movement in Baluchistan. This is Pakistan’s largest province, covering 44 per cent of the country's area but where 60 per cent of the population live in abject poverty (Khan and Prasad 2010). Yet on 7 June 2010, it was reported that Pakistan planned to increase its military budget to a massive 442 billion rupees (the equivalent of £3.59bn) (Morning Star 2010).

On 7 June 2010, the Independent reported that US special forces were operating in more than 75 countries - from Colombia to the Philippines. The "secret war" had vastly increased in scope and size under President Obama (Sengupta 2010a). No other information was forthcoming. Columnist Sam Leith (2010), in the London Evening 
Standard, commented critically: "It sounds...cool. But how, in principle - that is, in terms of accountability and respect for law - does dropping bombs from drones or fielding teams of assassins in other countries differ from the secret bombing of Cambodia in Kissinger's day?”

\section{UK battles: beyond the glare of the media}

In fact, since 1945 the UK and the US have deployed troops some where in the globe at least once every year - most of them far away from the gaze of the media. As Steve Peak (1982: 10) pointed out, the Falklands “war” of 1982 was the $88^{\text {th }}$ deployment of British troops since 1945 . These deployments took place in 51 countries and nearly all of them in Africa, the Middle East, South-East Asia, the Far East and around the Caribbean. Newsinger (1989) describes British intervention in Indonesia in 19451946 as a “forgotten war”. Britain’s longest running post-1945 campaign (leaving aside Northern Ireland) was in Malaya from 1948 to 1960. But this was never described as a war. Rose (1986) argued that British troops had been involved in more wars in more places across the globe than any other country since 1945.

In the case of the US, the investment in secret warfare is still greater than that of the UK. Cecil Currey (1991: 72-73) argued that since 1950, America had used either force or its threat about 500 times, mostly in Third World countries. Former CIA agent John Stockwell (1991: 70-73) suggests that the agency had been involved in 3,000 major operations and 10,000 minor operations which had led to the deaths of 6m people worldwide - mainly in Korea, Vietnam, Cambodia, Africa and Central and South America. It had overthrown functioning democracies in more than 20 countries and manipulated dozens of elections. During the 1980s, secret support from CIA and 
MI6 (the UK's foreign intelligence service) for the mujahedin in their fight against Soviet occupiers in Afghanistan ultimately helped in the creation of the "Taliban" (not an organisation with a convention command structure but a disparate insurgency involving many, largely Pashtun, groups) and al-Qaeda. As John Pilger recorded (2003):

For 17 years, Washington poured \$4bn into the pockets of some of the most brutal men on earthy - with the overall aim of exhausting and ultimately destroying the Soviet Union in a futile war. One of them, Gulbuddin Hekmatyar, a warlord particularly favoured by the CIA, received tens of millions of dollars. His speciality was trafficking opium and throwing acid in the faces of women who refused to wear the veil. In 1994, he agreed to stop attacking Kabul on condition he was made prime minister - which he was.

Special forces, such as the UK's SAS and the American Navy Seals, which are so crucial to secret warfare strategies, reportedly played important roles in the build up to the 1991 Iraq conflict and during them. They were the subject of a series of “inordinately flattering” features in the US and UK media (Ray and Schaap 1991:. 11). Yet accounts of their daring deeds of courage and endurance, since they were shrouded in almost total secrecy, amount to a form of fiction (see de la Billière 1995: 319-338; Hunter 1995: 169-175; Kemp 1994: 191-197).

By 2010, covert military action lay at the heart of US/Nato strategy in Afghanistan, the Middle East, the Horn of Africa and elsewhere. On 26 May 2010, both the Guardian and Independent followed up a report in the previous day's New York Times 
that General David Petraeus, head of the US’s Central Command, had signed a directive (called the Joint Unconventional Warfare Task Force Execute Order) on 30 September 2009. Under its provisions, special forces such as Navy Seals and the Army’s Delta Force would be able to "penetrate, disrupt, defeat or destroy” terrorist organisations, allowing for the assassination of US citizens abroad suspected of being terrorists (Cornwell 2010a; MacAskill 2010). ${ }^{5}$ Significantly, America’s top commander in Afghanistan in 2010, Gen. Stanley McChrystal, had headed the Joint Special Operations Command between 2003 and 2008.

In an accompanying comment piece, Rupert Cornwell, in the Independent, expressed support for the move. By following in the footsteps of President George Bush in his expansion of special force operations, US President Barack Obama had shown that he was “above all a realist and a pragmatist” (Cornwell 2010b). He continued: "Politically, Mr Obama must be seen as tough on national security. And if the CIA has many critics, no one doubts the quality of the US military.” An unsigned, hagiographic profile of McChrystal in the Sunday Times of 4 October 2009 described him as a "ruthless US special forces hunter killer”, a "mild, thoughtful and at times humorous soldier" and a "gaunt ascetic who rises at $4.30 \mathrm{am}$, eats one meal a day and jogs for an hour”. ${ }^{6}$

\section{Low Intensity Conflict (LIC)}

The second New Militarist strategy is known in militaryspeak as Low Intensity Conflict (LIC): this involves the day to day grind of long-drawn-out engagement; occasional small-scale skirmishes with the enemy, sometimes involving pilotless drones and Apache helicopters; the taking out of snipers and the removal of roadside 
bombs. The regular reporting from Afghanistan of British soldier casualties (“our Heroes”), more than 300 by June 2010, is part of the sporadic coverage of this LIC, counter-insurgency strategy.

Pentagon adviser John M. Collins, in his seminal analysis of LIC, points out (1991: 4): “All LICs are contingencies and technically transpire in peacetime because none have yet been declared wars.” Focusing on just 60 examples over the last century, Collins shows that 33 per cent of his sample exceeded 10 years while 57 per cent lasted less than five years. A feature of American strategy since the beginning of the $20^{\text {th }}$ century, it developed still further as an offshoot of the nuclear stand-off between East and West during the Cold War and in response to the US defeat in Vietnam.

As Halliday (1989: 72) argued: "LIC theorists insisted that US combat forces should not be involved in the long-run, Vietnam style operations. The 'lesson’ drawn here from Vietnam was that the US effort failed because it was too direct and too large.” Significantly Collins’ sample showed LICs mounting substantially in the post Vietnam, New Militarist era. During the 1980s, LIC strategists “came out” in the US and UK, numerous conferences were held and strategy documents were compiled exploring the concepts. But the LIC debate was largely ignored by the mainstream media.

\section{Manufactured “wars” and “operations”}

Finally, there are the occasional manufactured, media-hyped "operations” such as the attack on Musa Qala in December 2007, dubbed “Operation Snake Bite” (Grey 2009b), ${ }^{7}$, “Operation Panther’s Claw”, focusing on Garmsir, Nad-e-Ali and 
Khanashin, in June 2009. And the one dubbed "Moshtarak”, launched in February 2010. In these “operations”, the nation with the largest and most heavily resourced fighting force in history, faces a comparatively small movement - though one which is highly skilled in guerrilla tactics - in one of the most impoverished countries in the world. These “operations” are then spectacular, essentially PR events providing the theatre in which the US and its allies can claim their so-called "victories".

They emerge from a long history of changing military strategies (driven by capitalism's relentless drive for minerals and foreign markets) which can be dated back to the mid-nineteenth century. ${ }^{8}$ MacKenzie (1984) has described the “spectacular theatre" of $19^{\text {th }}$ century British militarism when press representations of heroic imperialist adventures in distant colonies had a considerable entertainment element. Featherstone, too (1993; 1993a) has identified the way in which the Victorian "small” wars of imperial expansion in Africa and India were glorified for a doting public by correspondents such as William Russell, G. A. Henty, Archibald Forbes and H.M. Stanley.

But Victorian newspapers and magazines did not have the social penetration of the mass media of today. And Victorian militarism was reinforced through a wide range of institutions and social activities: the Salvation Army, Church Army and uniformed youth organisations, rifle clubs, ceremonial and drill units in factories. "In all these ways, a very large proportion of the population came to have some connection with military and paramilitary organisations” (MacKenzie op cit: 5-6). By the 1980s, this institutional and social militarism had given way to a new mediacentric, consumerist, 
entertainment militarism in which the mass media, ideologically aligned to a strong and increasingly secretive state, had assumed a dominant ideological role.

The traditional, industrialised militarism of the First and Second World Wars, in which the mass of the population participated in the war effort, either as soldiers or civilians, was founded on the widespread fear that the British state faced serious threats to its very existence. By the 1980s the supposed "threats" to Western interests came from puny Third World countries: and so the role of the media in these New Militarist adventures became even more critical in manufacturing the enemy as a credible "threat". During the 1980s, the military adventures of the UK in the Falklands (1982), the US in Grenada (1983), Libya (1986) and Panama (1989), culminating the Iraq conflict of 1991, all bore the hallmarks of this new military/media strategy.

- The threats posed to US/Western interests, in all these military interventions were either grossly exaggerated or non-existent. Significantly, the failure of the Soviet Union to intervene militarily in Poland in 1981 to crush the Solidarity movement under the leadership of Lech Walesa proved to the Western elites that the threat posed by their traditional "enemy” was waning. And so the permanent war economies of Britain and America (with their military/industrial complexes) needed the manufacture of "big enemies" to legitimise the continued massive expenditure on the weapons of war. Hence the massive displays of US/UK force in all these adventures bore little relation to the threats posed. 
- They were all quickie attacks. The Libya bombings lasted just 11 minutes. All the others were over within days.

- They were all largely risk free and fought from the air. Since reporters were banned from accompanying pilots on the fighter jets, then the crucial air war was conducted largely in secret.

- All the attacks resulted in appalling civilian casualties. Yet the propaganda, in Orwellian style, claimed the raids were essentially for peaceful purposes. Casualty figures were covered up and the military hardware was constantly represented as “precise”, “surgical”, “modern” and “clean”.

- Central to the new strategy was the demonisation of the enemy leaders. In the absence of any serious military force, this demonisation served to represent the enemy states as credible threats.

- Media pools were deployed largely to keep journalists away from any action.

- All the invasions were celebrated in ecstatic language throughout the mainstream media. The editorial consensus remained firmly behind the military attacks. Administration lies were rarely challenged just as the global protests against the actions were largely ignored.

Defeat in Vietnam had proved to be a terrible trauma to the American military and political elites. With the waning of Soviet power in the 1980s, American imperialism could operate largely unchallenged. Victories were gained - and yet they were gained against largely puny Third World countries. The "Vietnam syndrome" could only be kicked in a "big" war. And Iraq's invasion of Kuwait in August 1990 was to prove the perfect opportunity for the manufacture of this perfect "big” war. 
The New Militarist strategy was to continue well into the new century. Media-hyped, spectacular “wars” were waged - as in Somalia (1992-93), Serbia (1999), Afghanistan (2001) and Iraq (2003). With reporters embedded alongside the military, coverage remained tightly controlled. Low intensity conflicts were continuing in Somalia, Afghanistan and Iraq - and occasionally "major operations”, where the US-led forces could claim victories against strangely shadowy enemies, were celebrated in the press.

\section{No basis in international law}

The Afghanistan conflict launched in 2001 following the 9/11 outrages in the US clearly had little basis in international law. So, in these "operations”, the essential role of the media embedded with the military and constrained by the enormous risks involved in reporting from such a lawless country, is to manufacture the image of legitimate, heroic so-called “warfare” against a credible threat. In other words, the conventional language of the military is deployed to describe completely asymmetrical conflict. As Bishop points out (op cit: 13):

Wars with insurgents were always unbalanced. One side had modern conventional weapons. The other fought with what was cheap, portable and easily improvised. But in Afghanistan the scale of the asymmetry at times seemed blackly absurd.

In the process the reality of the conflict, the high-tech violence of the invading forces, the appalling suffering of the Afghan people, is kept secret from the British public. We know precisely how many Coalition troops are killed (all of them, indeed, tragic and unnecessary), their names, their family histories - and how many have been 
wounded. As James Cogan noted on 23 April (2010): “Since 2001, the lives of 1,733 US and Nato troops have been squandered in Afghanistan...At least another 8,000 have been wounded in action, including more than 5,000 Americans. Thousands more have suffered non-battle injuries and illness.” In 2009 alone, there were 1,400 British casualties flown from Afghanistan to the UK, 212 in a critical condition (Willetts 2010). ${ }^{9}$ But the Afghan casualties of US/UK and Taliban attacks remain largely nameless and unknown. According to a report in Le Monde (Follorou 2010), almost 5,000 (grossly under-funded) Afghan policemen , with more than 70 per cent of them estimated to be illiterate, had been killed since 2003. ${ }^{10}$ Moreover, the Marjah offensive had created an estimated 27,000 internal refugees - but these are hardly ever reported in the media (Boone and Norton-Taylor 2010).

Indeed, the Taliban, supported by their al-Qaeda allies, are distinguished largely by their invisibility in the media. They lay booby traps and roadside bombs otherwise known as improvised explosive devices (IEDs: usually home-made from fertiliser ${ }^{11}$ ), snipe at their enemy - and flee (often on battered motorbikes).In the military jargon, this is known as "shoot and scoot" (Bishop op cit: 73). Over the six-month period up to June 2010, British soldiers had come across more than 500 IEDs and engaged in more than 1,300 gunfights in central Helmand (Norton-Taylor 2010c). IEDs were accounting for 80 per cent of British injuries and fatalities (Rayment 2010). Many of the guns the Taliban were using date back to the 1890s (Sengupta 2010b). As Turse and Engelhardt stress (op cit):

Al-Qaeda has no tanks, Humvees, nuclear submarines, or aircraft carriers, no fleets of attack helicopters or fighter jets...Al-Qaeda specialises in low-budget 
operations ranging from the incredibly deadly to the incredibly ineffectual...In the present war on terror, called by whatever name (or, as at present, by no name at all), the two "sides" might as well be in different worlds. After all, al-Qaeda today isn't even an organisation in the normal sense of the term, no less a fighting bureaucracy. It is a loose collection of ideas and a looser collection of individuals waging open source warfare.

Suicide bomb attacks and assaults on areas suspected of siding with the occupying forces have been other Taliban guerrilla tactics. In 2003 there were only two suicide attacks in Afghanistan. In 2006, there were at least 136, six times more than the year before. Eighty were directed at military targets but killed eight times as many civilians as soldiers or policemen (ibid: 130-131). The Taliban also terrorise individuals and communities suspected of siding with the occupation forces. According to Julius Cavendish (2010a), the insurgents executed two civilians whom they suspected of aiding government and international forces every three days during 2009.

Journalists have also been targeted. The decapitation of Afghan reporter Ajmal Naqshbandi, in 2007, was filmed and distributed on the internet ${ }^{12}$ - but this did not receive the global media attention given to the similar decapitation of the Wall Street Journal's Daniel Pearl, in February 2002. ${ }^{13}$ The Guardian's foreign correspondent Ghaith Abdul-Ahad was released along with two other journalists in December 2009 after being held hostage for six days in a remote region of Afghanistan (Taylor 2009). In January 2010, Rupert Hamer, embedded with US Marines at Nawa in Helmand for the Sunday Mirror, became the first UK journalist to be killed in Afghanistan. And this received massive media coverage. The front page of the Daily Mirror of 11 
January carried a large photograph of Hamer smiling in front of troops with the headline: "Fine, fearless, dedicated” (Hughes 2010). ${ }^{14}$

The Taliban's basic weapon is an AK-47 rifle of Second World War design, augmented by machine guns and latterly home-made roadside bombs. In addition, the "legacy mines" left over since the time of the Soviet occupation (1979-1989) pose a durable threat. Facing them, the US-led troops have state-of-the art satellites, spy planes and unmanned drones. Writing in 2009, Patrick Bishop commented in his book celebrating the heroics of 3 Para Battlegroup in Afghanistan (op cit: 12):

Anti-American rebels had made great use of IEDs and suicide bombs in Iraq but they had been late arriving in Afghanistan [since 2006]. Together they now kept the troops in a constant state of alertness and anxiety. The insurgents' new methods carried less risk to themselves than did their previous confrontational tactics. Even when they suffered losses, though, there seemed to be no shortage of replacements.

With Osama bin Laden and Mullah Omar having mysteriously fled into the unknown following the US invasion of 2001, the Taliban in 2010 had no leader - such as the “mad dog” Gaddafi, of Libya, or the "new Hitler, Butcher of Baghdad” Saddam or the "Butcher of Belgrade”, “Slobo” Milosevic - on whom our patriotic editors safe in their Fleet Street bunkers and the military could direct their venom. The Taliban had no headquarters which US precision-guided missiles could “take out”. 
On 17 February 2010, the media reported American claims that the actual head of the Taliban’s military operations had been seized in Karachi: a certain Mullah Abdul

Ghani Baradar. ${ }^{15}$ But like the rest of the Taliban, Mullah Abdul remains a shadowy, unknown figure. Significantly, no photographs of Taliban’s toppled No 2 accompanied the reports.

\section{Moshtarak: billed as the "biggest US offensive since 2001"}

Operation Moshtarak, launched on 12 February in Afghanistan, was billed as "the biggest US military offensive since the US invasion of 2001” (note how PR-ish superlatives always accompany every new assault by the American military).

The 15,000 Coalition forces drawn from the US, the UK, Canada, Denmark, Estonia and most significantly Afghanistan were equipped with a vast arsenal - including Apache, Chinook and Cobra, Black Hawk attack helicopters and unmanned predator aircraft - all of it backed up by ranks of military intelligence operatives and information gathering hi-tech satellites. But whom were they "battling”? Possibly just 400 Taliban, according to some US officers (Lamb 2010). On 7 February, the Sunday Times predicted just 1,000 Taliban would be facing the 4,000 crack British troops (Colvin 2010). For the follow-up Kandahar offensive planned for the summer, military intelligence were said to be expecting between just “500 and 1,000” insurgents (Kirkup 2010).

So this is an "operation”: not real warfare. Rather, it’s a simulated, mediacentric event providing a symbolic show of US/UK military strength and proof that the new Afghan army is capable of taking over once the occupying forces withdraw. The operation 
had certainly no credible strategic legitimacy. The target of the US-led assaults was Marjah in Helmand province in the south of the country. But as reporter Anand Gopal told the progressive Democracy Now! radio station Marjah was “a very tiny town”. Gopal continued:

It's more a show of force by the coalition forces, something they can offer their home audiences of how they’ve gone into a village and retaken some Taliban. But beyond that, nothing will really change on the ground, regardless of what happens in Marjah. It's just business as usual. ${ }^{16}$

Investigative reporter Gareth Porter (2010b: 8) claimed that the picture of Marjah presented by military officials and obediently reported by major news media was "one of the clearest and most dramatic pieces of misinformation of the entire war, apparently aimed at hyping the offensive as a historic turning point in the conflict”. On 2 February 2010, Associated Press quoted “Marine commanders” saying they expected 400 to 1,000 insurgents to be "holed up" in the southern Afghan town of 80,000 people”. According to Porter, "that language evoked an image of house-tohouse urban street fighting”. On 14 February, the second day of the "offensive”, Lt Josh Diddams said the Marines were "in the majority of the city at this point”. He also used the language that conjured images of urban fighting, claiming the insurgents were hold some "neighbourhoods". Yet, as Porter stressed, Marjah is not a city nor even a real town but either a few clusters of farmers' homes or a large agricultural area covering much of the southern Helmand River Valley.

\section{Maintaining the myth of warfare}


Predictably the Coalition forces were reported as “storming” Marjah. More superlatives appeared in the press to manufacture the image of credible warfare: the town was suspected of being "one of the biggest, most dangerous minefields Nato forces had ever faced” (Martin 2010). Brig Gen. Larry Nicholson, commander of the Marines in southern Afghanistan, was quoted as saying: "This may be the largest IED threat and largest minefield that Nato has ever faced.” while the US military were reported as saying that "hundreds of beleaguered insurgents could insist to fight until death” (ibid).

On 13 February Gulab Mangal, governor of Helmand, was reported as saying it was “the most successful operation we have ever carried out”. Duncan Larcombe (2010), embedded with the Fire Support Company, $1^{\text {st }}$ battalion, the Royal Welsh, in the Sun of 15 February trumpeted: “Our boys are in high spirits after successfully pulling off the largest helicopter assaults in British military history.” Oliver Harvey (2010), embedded with 3 Platoon Queen's Company for the Sun, celebrated the flying of the Afghan national flag at the "Taliban stronghold Marjah" as a "sign of hope”.

Always the myth of warfare survives: usually as a future danger. So the Sun of 11 February reported: "Fighting ....in Helmand is expected to be ferocious.” In the Sunday Times of 14 February Miles Amoore and Marie Colvin reported (2010): "Most Taliban appear to have scattered before the onslaught which was strongly signalled in advance. However, military commanders expect them to regroup and attack in the weeks ahead.” And Jon Boone (2010b) in the Guardian of 10 March quoted Commanding officer Major Joseph Brannon on the Taliban: “They know we are making a difference here so we are expecting a pretty strong fight.” 
But as John Pilger (2010) commented: “The recent 'liberation of the city of Marja' from the Taliban’s ‘command and control structure’ was pure Hollywood. Marja is not a city - there was no Taliban command and control. The heroic liberators killed the usual civilians, the poorest of the poor. Otherwise is was fake. A war of perception is meant to provide fake news for the folks back home to make a failed colonial adventure seem worthwhile and patriotic.”

\section{The celebritisation of "heroic" warfare}

One way in which the media hide the reality of the horror of warfare is to celebrate the visits of celebrities from the world of politics and entertainment to the troops on the frontlines. The events are pure PR - being usually accompanied by photographs of the smiling visitors shaking hands with equally smiling troops or trying some of the military hardware for the cameras. The language used is always positive and uplifting. Typical, then, was the coverage given to President Barack Obama on 29 March 2010 on his first visit to the war zone since ordering a "surge" of 30,000 extra US troops in Afghanistan in November 2009. Stephen Foley (2010), in the Independent, quoted the President: “I’m encouraged by the progress that's been made... One of the main reasons I am here is just to say than you for the extraordinary efforts of our troops.”

On 24 May, the Daily Mail along with the rest of Fleet Street reported David Beckham, England football "hero", dropping in on the troops in Camp bastion, Afghanistan. He told troops of his "huge admiration" for them. ${ }^{17}$

\section{Fleet Street backs Moshtarak offensive - despite massive public opposition}


Virtually all the New Militarist attacks have won the overall support of Fleet Street editors: Operation Moshtarak, involving 9,500 British troops, was no exception. For the 1991 conflict all Fleet Street newspapers backed the military response together with 95 per cent of columnists. For the 1993 and 1998 attacks on Iraq the consensus fractured with the Guardian, Independent and Express coming out against the attacks. Then for the Nato attacks on Serbia in 1999 virtually all of Fleet Street backed the action, even calling for the deployment of ground troops (which not even the generals dared adopt as policy). There was one exception - the Independent on Sunday - and its editor, Kim Fletcher, left the paper just weeks after the end of the conflict. But there was far more debate amongst columnists. A survey I conducted showed 33 out of 99 prominent columnists opposed military action against Serbia. For the attacks on Afghanistan and the toppling of the Taliban, the whole of Fleet Street backed the action - but again there was a wide-ranging debate amongst columnists and letter writers (Keeble 2004 and 2007).

In 2003, with significant opposition to the rush to war being expressed by politicians, lawyers, intelligence agents, celebrities, religious leaders, charities and human rights campaigners - together with massive street protests - both nationally and internationally, the breakdown in Fleet Street's consensus was inevitable. Yet still for the invasion of Iraq, the vast bulk of Fleet Street backed the action (though columnists and letter writers were divided). The Independents, carrying prominently the dissident views of foreign correspondent Robert Fisk, were the most hostile. Following the massive global street protests on 15 February, the Independent on Sunday editorialised: “Millions show this is a war that mustn’t happen.” 
The Guardian did not criticise military action on principle but opposed the US/UK rush to war and promoted a wide range of critical opinions. The Mirrors were also "anti” in the run up to the conflict (perhaps more for marketing reasons since the Murdoch press was always going to be firmly for the invasion) with the veteran dissident campaigning journalists John Pilger and Paul Foot given prominent coverage. But then, after editor in chief Piers Morgan claimed his papers' stance attracted thousands of protesting letters from readers, their opposition softened. And the Mails managed to stand on the fence mixing both criticism of the rush to military action with fervent patriotic support for the troops during the conflict.

In 2010, most of Fleet Street was still backing the Nato "war” in Afghanistan. On 6 December 2009, the Sunday Times editorial, titled "Prepare for the long haul in Afghanistan”, welcomed President Obama’s “surge” strategy: “He took his time, but President Barack Obama reached the right decision with his announcement last week the United States is to send 30,000 more troops and 250 helicopters to Afghanistan.” On 14 February the same newspaper was hailing, cautiously, Operation Moshtarak: "Maybe this is the end of the beginning". According to the Independent's editorial of 9 February 2010, the strategy of General Stanley McChrystal, to put Afghan troops alongside Western troops, had "logic” and "should at least be given an opportunity to prove itself”.

On 2 June, the Daily Telegraph editorialised: "The heroic work undertaken by the British forces these past four years has laid the foundations for the new American-led strategy.” The Guardian's editorial on the following day suggested the British government "could make a bold decision - to withdraw troops from the front, use 
them to secure Kabul and set themselves the more modest aim of doing things that work”. But by 24 June 2010, the Guardian was describing the war as “dysfunctional” and “unwinnable”. According to The Times' editorial of 10 June 2010, the new Prime Minister, David Cameron "to his credit...has chosen to reaffirm the importance of success in Afghanistan and to offer unbridled support to the military”. A follow-up leader the next day concluded, firmly, that "at a time of austerity, it is imperative that this nation spends more on its defence”. But as during the Nato attacks on Serbia in 1999, the Independent on Sunday dared to stand outside the consensus. On Remembrance Sunday, 8 November 2009, its editorial commented:

It is time, on this solemn day on which we remember the sacrifice of those who gave their lives for our freedom and security, for a change in policy. It is time to say that this war was ill-conceived, unwinnable and counterproductive. It is time to start planning a phased withdrawal of British troops.

Fleet Street's general support for the UK government's Afghan strategy did not match the public mood with polls consistently calling for troops to be withdrawn (Milne 2009). In July 2009, the BBC/Guardian, ITN, The Times and Independent all published polls showing Britons wanted immediate or rapid withdrawal of troops. Yet Polina Aksamentova argued (2009) that the media largely downplayed their findings. For instance, the ICM study, reported in the Guardian on 11 July, found 42 per cent wanted Britain to pull out immediately and 14 per cent by the end of the year. The Guardian, however, titled the article "Public support for Afghanistan is firm, despite deaths". It stressed that support for the war had increased from 30 per cent in 2006 to 
46 per cent but left the call for withdrawal to the last three sentences of the article. Few of the newspapers wrote about any of the other polls.

On11 November 2009, the Independent published a vote showing four out of five did not believe the government's main justification - and did not believe that British involvement was keeping the streets of Britain safe from terrorist attacks. Some 46 per cent felt the war actually increased the threat of attacks by creating anger and resentment among the Muslim population (Sengupta and Morris 2010). Even while Operation Moshtarak was under way, another poll by ComRes for the Independent and ITV News showed that almost three-quarters of electors viewed the conflict as unwinnable - and more than half said they did not understand why British troops were still in Afghanistan (Morris 2010). Similar massive public opposition to the war was being recorded in the US. A Washington Post/ABC poll released in June 2010 showed 53 per cent of respondents saying the war was "not worth fighting” - the highest percentage in three years. ${ }^{18}$

Opposition has appeared in the mainstream media from a number of prominent columnists - such as Simon Jenkins, Seamus Milne, Peter Preston (all Guardian), Andreas Whittam Smith, Johann Hari (Independent), Max Hastings and Andrew Alexander (Daily Mail), Jeff Randall (Daily Telegraph), Peter Beaumont (Observer) and Denis McShane MP. But, intriguingly, the loudest protests in the media have come largely from those calling for still more investment in the war. The Sun, Mail, Express and Telegraph, to name but a few of Fleet Street's most hawkish members, criticised loudly the supposed failures of the Gordon Brown New Labour government to equip “our heroes” properly. Particular attention has focused on the alleged failings 
of the Snatch Land Rover (Sturke 2008; Bulstrode 2010). The claims of a Catholic bishop at a military funeral that soldiers in Afghanistan urgently needed more helicopters and vehicles in late April 2010 received substantial media coverage (e.g Bowcott 2010).

The row promoted an illusion of critical media holding the rulers to account. And yet the controversy was entirely manufactured. The US military have spent around one trillion dollars on its post 9/11 wars so far (Stiglitz and Bilmes 2009); it has 1.4 million active duty men and women and another 1.3 million reserve personnel; it employs more than 700,000 civilians in support roles while there are estimated 100,000 members in its civilian intelligence community. Its military budget in 2009 amounted to $\$ 661$ billion. ${ }^{19}$ In June 2010, Congress was set to approve an “emergency” supplemental financing Bill including more than \$33 billion, mainly for funding the American military “surge” in Afghanistan (Astore 2010). Britain had already spent $£ 9.4$ billion on its Afghanistan operations by 2010 (Turse and Engelhardt op cit; see also Turse 2008). It annual military spending was the equivalent of $\$ 53.8$ billion, the fourth highest in the world (after the US, France and China). ${ }^{20}$ So much for under-resourcing.

“Operations" certainly help provide a "theatre” in which some of these massively expensive weapons and the various branches of the military (army, navy, air force, special forces, satellites, intelligence and so on) can be tested. Significantly, Adam Ingram, a former Armed Forces Minister, suggested that a desire within the army to try out a new range of recently purchased Apache helicopters was a factor in the deployment of British troops to Helmand in 2006 (Haynes 2010). Before the 3,000 
British troops arrived, the province had been "relatively quiet”, according to Andrew Krepinevich, who served on the personal staff of three US secretaries of defence, but their arrival “stirred up a hornet’s nest” (Evans 2010).

\section{The contradictions of New Militarism and the failure of Operation Moshtarak}

Central to manufacture of New Militarist "operations" is the celebration of "victory" to applauding home audiences usually just days after their launch. But since 2001 and the US/UK invasions of Afghanistan and Iraq, the New Militarist strategy has faced significant setbacks. The occupations of Iraq and Afghanistan have attracted massive opposition from local forces and, by 2010, substantial majorities in the UK were calling for the troops to be withdrawn from Afghanistan.

Thus while the US/UK military remained committed to the launch of media-hyped “operations”, by 2010 they were often no longer achieving their desired results. In the case of Operation Moshtarak, its launch was given predictably massive media coverage yet its conclusion was hardly covered at all. Almost immediately after, the focus shifted to US plans to take over Kandahar, Afghanistan’s second city, in the summer. Typical was the report by Julius Cavendish (2010), in the Independent of 21 April 2010. Buried in the coverage of the assassination of the deputy mayor of Kandahar in a mosque was a comment from provincial council member Haji Moqtar Ahmed on Operation Moshtarak: "My thinking is [there was] no result. It failed...If they start without consulting ordinary people, thousands of families will move to Kandahar city. There will be great misery.” And Cavendish added: 
Nato’s strategy for Kandahar was partly tested in its campaign to restore government control over the town of Marjah in neighbouring Helmand. The campaign, which began in February, has been held up by the Taliban.

The Morning Star reported in early May 2010 that resistance forces continued to operate in Marjah and that locals had largely refused to collaborate with occupation troops or Karzai government officials (Mellen 2010). Kim Sengupta (2010e) reported on 28 May 2010 claims by Hajj Mohammad Hassan, a local tribal elder, that there remained no security in Helmand. "By day there is government. By night it’s the Taliban.” The Guardian’s editorial of 3 June 2010 commented: “The Marjah campaign, which was designed as a blueprint for how the Taliban could be rolled back, has become - in Gen McChrystal's words - a bleeding ulcer of the campaign. There could be bigger wounds yet.” On 9 June 2010, the BBC reported Nato and Afghan official claiming "success" for the Marjah campaign, but there were reports of continuing violence and Taliban intimidation. ${ }^{21}$ And by 17 June, the writer and historian, William Dalrymple (2010), reported:

...it appears that the Taliban have regained control of the opium-growing centre of Marjah in Helmand province, only three months after being driven out by McChrystal's forces amid much gung-ho cheerleading in the US media

Serious splits over strategy for the planned summer, follow-up "operation” in Kandahar, amongst military and civilian leaders in both the UK and US, also surfaced prominently in the media (e.g. Helm and Beaumont 2010; Sengupta 2010c). ${ }^{22}$ They culminated (amazingly) in the sacking of Gen. McChrystal by President Obama on 23 
June 2010 after his outspoken criticisms of the civilian leadership of the US were published in Rolling Stone magazine. Moreover, Nato officials were warning that there were no quick, New Militarist fixes in Afghanistan with British and foreign troops expected to be engaged in a combat role there for at least three or four more years (Norton-Taylor 2010d).

The performance of local Afghan forces in Operation Moshtarak was also disappointing, according to reports. It was thrown into further disarray with the resignations of two of the "most internationally respected" members of Karzai's government - interior minister Hanif Atmar and spy chief Amrullah Saleh - after a gathering of 1,600 leaders in Kabul came under Taliban rocket attack (Boone 2010). Moreover, a survey of 1,994 people in Afghanistan, commissioned by Gen. McChrystal found that 85 per cent viewed the Taliban as “our Afghan brothers”. More than two thirds said they viewed Karzai’s government as totally corrupt while the occupying forces and Afghan police were considered the greatest threat to personal security by 56 per cent (Cogan op cit).

\section{Missing from the coverage: the massive, global opposition}

Largely missing from the Moshtarak coverage is any acknowledgement of the views and protests of the massive anti-war movement in this country and globally. CND, the Anti-War Coalition, War Resisters International, the Peace Pledge Union, Pax Christi, Campaign Against the Arms Trade, Respect are but a handful of the many groups in the UK largely ignored by the mainstream. On 3 April 2010, for instance, PressTV reported that thousands of peace activists had taken to the streets in 30 towns and 
cities across Germany demanding an immediate end to the country's unpopular presence in Afghanistan. ${ }^{23}$

While the mainstream media, with a few notable exceptions (such as veteran reporter Kathy Gannon of Associated Press, Patrick Cockburn and Robert Fisk, of the Independent, Jonathan Steele, of the Guardian) are failing in their coverage of Afghanistan there are still some excellent reports in alternative media to be accessed via the internet. To name but two: TomDispatch.com, edited by the US historian Tom Engelhardt, has carried a series of excellent investigative pieces on the conflict contextualising it historically and highlighting the vast military industrial complex which is promoting it. The Indian journal Frontline (at www.frontlineonnet.com) has also a history of covering US imperialistic adventures with a detailed and critical eye (while other useful websites are listed towards the end of this chapter). For journalism students and critical media consumers there are, indeed, many models out there of good, brave reporting to admire and learn from.

Professor Richard Lance Keeble wishes to acknowledge the comments made by Prof John Tulloch on a draft, but remains entirely responsible for this final copy. It is based on the talk he gave on 18 March 2010 to an international conference on the Afghan media coverage organised by John Mair, of the journalism department at Coventry University.

\section{Notes}

\footnotetext{
${ }^{1}$ At a time of general spending cuts (imposed by the government as a response to the global credit crisis and in an attempt to reduce the massive national debt) the defence budget was due to be increased in 2010 by more than $£ 500$ million to $£ 38$ billion (Norton-Taylor 2010b). David Swanson (2010) reported that Congress was expected to vote on $\$ 33$ billion extra war funding for the Afghan troop
} 
“surge”. According to the Congressional Budget Office, Congress had already approved \$345 billion for the war in Afghanistan and \$708 billion for the Iraq war. Government figures released on 19 June 2010 showed that Britain had spent at least $£ 9.24$ billion in Iraq and $£ 11.1$ billion since 2001 . The actual cost, which did not include soliders' salaries or caring for the wounded, was expected to be much higher (see http://news.bbc.co.uk/1/hi/uk/10359548.stm, accessed on 20 June 2010). The Pentagon also spends an enormous amount on fuel. In 2009 alone, according to the Pentagon's Defense Energy Support Centre, the military spent $\$ 3.8$ billion on 31.3 million barrels (around 1.3 billion gallons) of oil consumed at posts, camps and bases overseas. Another $\$ 974$ million was spent by the ground-fuels division just on the Afghan war in 2009. Also in 2009, the military awarded $\$ 22.5$ billion in energy contracts. The largest contractor was BP which received more than $\$ 2.2$ billion - almost 12 per cent of all petroleum-contract dollars awarded (see http://www.lobelog.com/tomgram-nick-tursebp-and-the-pentagons-dirty-little-secret/, accessed on 18 June 2010)

${ }^{2}$ After the killings of civilians during a night raid provoked massive protests in eastern Afghanistan, Nato commander Gen. Stanley McChrystal ordered his troops to avoid night raids (see Afghanistan: Protest erupts over Nato killings, Morning Star, 15-16 May 2010). Nato spokesman Gen. Joseph Blotz claimed in June 2010 civilian casualties had fallen by 44.4 per cent over the previous three months due to more stringent rules of engagement (see:

http://news.bbc.co.uk/1/hi/world/asia_pacific/10356741.stm)

${ }^{3}$ According to Turse (2010), quoting Colonel Kevin Wilson, head of the building operations in southern Afghanistan for the US Army Corps of Engineers, the Americans were spending \$3 billion on base-building in Afghanistan in 2010. In Iraq in August 2009, there were still almost 300 American bases and outposts. In addition to those in Iraq and Afghanistan, the Pentagon listed 716 overseas sites across the globe - especially in the Middle East, Europe, Japan and South Korea.

${ }^{4}$ See Evans and Norton-Taylor (2010). A freedom of Information request by the Guardian revealed that the RAF had fired 845 missiles from reaper drones since they were first deployed in June 2008. They plan to double the number of drones in use over the next two years. They are launched from a base in Kandahar by remotely controlled by a squadron of 90 RAF personnel at Creech US Air Force base in Nevada. Harvey (2009) reported that Predator drones were to rack up 1 million flight hours and that there were 35 Predators in the air at any one time. Harvey described the drones as being "so successful in the fight against the Taleban and a-Qaeda”. Focusing on the new Avenger drone, Harvey said it could fly practically undetected at 60,000ft and was being "fine-tuned" at Gray Butte flight operations facility of General Atomics Aeronautical Systems, Inc. But citing figures compiled by Pakistan's Interior Ministry, the Karachi-based daily, News International, reported that "Afghanistanbased US Predators carried out a record number of 12 deadly missile strikes in the tribal areas of Pakistan in January 2010, of which 10 went wrong and failed to hit their targets, killing 123 innocent Pakistanis” (van Auken 2010). Significantly, the US claimed in January 2010 that a drone attack had killed the head of the Pakistan Taliban, Hakimullah Mehsud in North Warzirstan. But in April 2010, new intelligence suggested that he had escaped - as the Taliban had always insisted (Buncombe and Waraich 2010; Walsh 2010a). In May 2010, the Americans claimed that Mustafa Abu al-Yazid, prominent in al-Qaeda in Afghanistan (and arrested over the killing of the Eyptian President Anwar Sadat in 1981), had been assassinated by missiles fired from a drone in Pakistan (Sengupta 2010d). His wife, three daughters and a granddaughter were all said to have also died in the attack. Al-Yazid was erroneously reported dead by Pakistan officials after a drone strike in August 2008 (Walsh 2010b) ${ }^{5}$ Kim Sengupta (2010b) reported that the law on assassinations was aimed specifically at future attempts to target Anwar al-Awlaki, suspected of being the mentor to the 2009 Christmas Day “underpants bomber” Umar Farouk Abdulmuttallab and US Army Major Nidal Malik Hasan who killed 13 people at Fort Hood in Texas in November 2009

${ }^{6}$ See http://www.iiss.org/whats-new/iiss-in-the-press/october-2009/profile-stanley-mcchrystal/, accessed on 1 May 2010

${ }^{7}$ A substantial genre of books has emerged celebrating the heroics of "Our Boys" in Afghanistan. They include Moore (2003), Scott (2008), Kemp, Hughes (2009) and Junger (2010). Geoff Dyer (2010) argues that writing in this non-fiction genre is best able to capture the essence of US-style warfare today: "Reportage, long-form reporting - call it what you will - has left the novel looking superfluous. The fiction lobby might respond: it's too soon to tell.” He adds: "We are moving beyond the nonfiction novel to different kinds of narrative art, different forms of cognition. Loaded with moral and political point, narrative has been recalibrated to record, honour and protest the latest, historically specific instance of futility and mess.”

${ }^{8}$ Significantly, the Mail Foreign Service reported on 15 June 2010 that untapped ore - including huge veins of gold, iron, copper, cobalt and industrial metals such as lithium - valued at more than £820 
billion had been discovered by geologists in Afghanistan. The article commented that the find "will also raise question marks over the motives behind the long and costly war launched in the wake of the 9/11 attacks”. Later in the same week, the Americans tripled the estimated value of the untapped mineral wealth to $\$ 3$ trillion.

${ }^{9}$ Some 23 of the 55 British deaths in Afghanistan from January to June 2010 had taken place around Sangin. Of the total Nato casualties of 1,849 on 21 June 2010 (drawn from the 25 countries of he coalition and including 125 US women), 1,125 were American, 147 Canadian, 44 French and 42 German (see Higginson, John, “Highest price must be paid”, Metro, 22 June). Soldiers were also suffering major psychological problems. In June 2010, some 20,000 ex-servicemen were in prison or on probation in Britain - one in ten of the jail population. Since of 1982, 264 veterans of the Falklands conflict of that year have committed suicide, compared with 255 who died in action (Newton Dunn 2010)

${ }^{10}$ The Americans, in addition to funding the Afghan police, had directed \$1 million on building up private security forces (see Follorou 2010). Yet these companies were operating in a "culture of impunity" that was encouraging lawlessness and corruption, according to Britain’s most senior commander in southern Afghanistan, Major General Nick Carter (Richard Norton-Taylor 2010e). According to investigative reporter Pratap Chatterjee (2010), the US had spent \$7 billion on police training since 2003 had left "the country of 33 million people with a strikingly ineffective and remarkably corrupt police force. Its terrible habits and reputation have led the inhabitants of many Afghan communities to turn to the Taliban for security”. Fears were also growing that the Taliban had infiltrated the Afghan police (Wintour and Norton-Taylor 2010)

${ }^{11}$ Accord to the Sun: "Evil Taliban improvised bombs are usually packed with filth - the the hope those they fail to kill outright die later from infection” (Willetts op cit). A UN Security Council report in June 2010 said that over the previous four months roadside bomb attackls rose by 94 per cent compared with the same period in 2009 while there were three suicide bombings every wee k. See: http://news.bbc.co.uk/1/hi/world/asia_pacific/10356741.stm

${ }^{12}$ See http://www.democracynow.org/2009/8/17/fixer_the_taking_of_ajmal_naqshbandi, accessed on 1 May 2010

${ }^{13}$ See http://www.truthtube.tv/play.php?vid=2795, accessed on 1 May 2010

${ }^{14}$ Colin Hughes, of the Daily Mirror, was later sent death threats after he posted a blog that criticised a charity motorbike ride through Wootton Bassett, through which pass the hearses carrying the bodies of repatriated soldiers (Milmo 2010). After more than 5,000 Facebook members called for a boycott of the Mirror, the newspaper apologised for Hughes’ posting

${ }^{15}$ Soon after the arrest of Baradar Pakistan arrested two more senior Taliban figures, Mullah Abdul Salam and Mullah Mir Mohammad. Mystery surrounded the arrests. Some commentators considered that Islamabad was shifting away from its secret support for the Taliban. But as Shah (2010) commented in the Guardian: “A more cynical interpretation suggested that instead of turning its back on the Taliban, Pakistan was simply putting pressure on them to come to the negotiating table." ${ }^{16}$ See

http://www.medialens.org/forum/viewtopic.php?t=3070\&sid=76d871d7f9209d50c8b991fc950f2a5d, accessed on 3 June 2010

${ }^{17}$ See also Patrick Mulchrone's report on Beckham's visit and his praise for the "fallen heroes" in the Daily Mirror, available online at http://www.mirror.co.uk/celebs/news/2010/05/24/becks-silence-forthe-fallen-115875-22280836/, accessed on I June 2010

${ }^{18}$ See http://www.wsws.org/articles/2010/jun2010/afgh-j19.shtml, accessed on 19 June 2010

${ }^{19}$ See http://www.globalfirepower.com/defense-spending-budget.asp, accessed on 4 June 2010.

Britain’s figure represented a \$3.7 billion increase on the previous year. Guardian columnist Simon Jenkins (2010) called for all the $£ 45$ billion defence spending “against fantasy enemies” to be cut 20 ibid

${ }^{21}$ See http://news.bbc.co.uk/1/hi/world/south_asia/10274262.stm, accessed on 9 June 2010

${ }^{22}$ Nato strategy in Afghanistan was thrown into further disarray with the resignation of the German President, Hörst Kohler, after he had suggested that military deployments were central to the country's economic interests (Connolly 2010)

${ }^{23}$ See inthesetimes.com/2010/04/03/german-easter-rallies-decry-afghanistan-killings, accessed on 4 May 2010

\section{References}


Aksamentova, Polina (2009) Withdrawal majority censored, Peace News, September, No 2513

Amoore, Miles and Colvin, Marie (2010) British spearhead allied offensive, Sunday

Times, 14 February

Astore, William, J. (2010) Doubling Down in Afghanistan, 3 June. Available online at http://www.tomdispatch.com/archive/175256/, accessed on 2 June 2010

van Auken (2010) Obama’s surge: killing spree on both sides of Afpak border.

Available online at http://www.wsws.org/articles/2010/feb2010/afpk-f03.shtml, accessed on 1 May 2010

de la Billière, Sir Peter (1995) Looking for Trouble: SAS to Gulf Command, London, HarperCollins

Bishop, Patrick (2010) Ground truth: Back on Afghanistan's frontline - 3 Para's epic new challenge, London, Harper Press

Boone, Jon (2010a) Afghan minister resigns over jirga attack, Guardian, 7 June Boone, Jon (2010b) Afghanistan: 24-hour patrols in Kandahar to win hearts and find mines, Guardian, 10 March

Boone, Jon and Norton-Taylor, Richard (2010) Poppy town that became deathtrap for British army, Guardian, 22 June

Bowcott, Owen (2010) Army shortages cost lives, bishop warns, Guardian, 29 April

Bulstrode, Mark (2010) Snatch Land Rovers blamed for dozens of deaths, Independent, 9 March

Buncombe, Andrew and Waraich, Omar (2010) Taliban leader was not killed by drone strike, says Pakistan, Independent, 30 April Borger, Julian (2009) Karzai’s brother in pay of CIA for eight years, US officials claim, Guardian, 29 October 
Cavendish, Julius (2010b) Mosque murder leaves Kandahar on edge, Independent, 21 April

Cavendish, Julius (2010b) Fighters switch back to Taliban after "broken promises”, Independent, 23 April

Chatterjee, Pratap (2010) Policing Afghanistan: How Afghan police training became a train wreck, 21 March. Available online at www.tomdispatch.com/blog/175220/, accessed on 3 June 2010

Cockburn, Patrick (2010a) The secret war - and the hidden lair of the Taliban, Independent, 16 April

Cockburn, Patrick (2010b) Caught in the crossfire of Pakistan’s secret war, Independent, 22April

Cogan, James (2010) Afghanistan: Another massacre as a bloody summer loons in Kandahar, 23 April. Available online at www.wsws.org/articles/2010/apr2010/afgha23.shtml, accessed on 24 April 2010

Collins, John M. (1991) America’s Small Wars, London/Washington, Brasseys (US)

Colvin, Marie (2010) Special forces assassins infiltrate Taliban strongholds in Afghanistan, Sunday Times, 7 February

Cornwell, Rupert (2010a) US to launch covert strikes on terror targets, Independent, 26 May 2010

Cornwell, Rupert (2010b) When it comes to terrorism, Obama is following Bush's lead, Independent, 26 May

Connelly, Kate (2010) German president quits amid accusations of 'gunboat diplomacy’ after Afghanistan gaffe, Guardian, 1 June 
Currey, Cecil (1991) Vietnam: lessons learned, Helling, Phil and Roper, Jon (eds), America, France and Vietnam: Cultural history and ideas of conflict, Aldershot, Avebury pp 71-90

Dalrymple, William (2010) The British army overwhelmed by Afghan warriors. No, not today but in 1842. So can we learn lessons of history before it happens again?, Dail Mail, 17 June

Dyer, Geoff (2010) The human heart of the matter, Guardian, 12 June Evans, Michael (2010) Complacent British ignored advice that force was too small. Say Pentagon officials, The Times, 10 June

Evans, Rob and Norton-Taylor, Richard (2010) RAF strategy in Afghanistan shifts to drones, Guardian, 8 February

Featherstone, Donald (1993a) Victorian Colonial Warfare: Africa, London, Blandford Featherstone, Donald (1993b) Victorian Colonial Warfare: India, London, Blandford Foley, Stephen (2010) Obama rallies the troops on surprise visit to Afghanistan, Independent, 29 March

Follorou, Jacques (2010) Le état d'âmes des policicers afghan, privés de moyens et minés par la corruption, Le Monde, 9 June

Gopal, Anand (2010) Afraid of the dark in Afghanistan, 28 January. Available online at www.tomdispatch.com/dialogs/print/?id=175197, accessed on 29 January 2010 Grey, Stephen (2009a) Operation Snake Bite: The explosive true story of an Afghan desert siege, London, Viking

Grey, Stephen (2009b) New elite force for Helmand, Sunday Times, 6 September Halliday, Fred (1989) Cold War, Third World: An Essay on Soviet-American Relations, London, Radius 
Harvey, Mike (2009) Avenger of the skies: next wave of drones takes off, Times, 3

October

Harvey, Oliver (2010) The Sun goes into Helmand with our brave army medics, Sun, 26 February

Haynes, Deborah (2010) The Whitehall brass and mandarins who set up the bloodiest mission since Korea, The Times, 10 June

Helm, Toby and Beaumont, Peter (2010) Cameron calls Chequers summit as strains grow over coalition's aims in Afghanistan, Observer, 30 May

Hughes, Chris (2010) Fine, fearless, dedicated, Daily Mirror, 11 January

Hunter, Robin (1995) True stories of the SAS, London, Virgin

Jenkins, Simon (2010) My once-in-ia-generation cut? The armed forces. All of them, Guardian, 9 June

Junger, Sebastian (2010) War, London, Fourth Estate

Keeble, Richard (2004) Information warfare in an age of hyper-militarism, Allan,

Stuart and Zelizer, Barbie (eds) (2004) Reporting War: Journalism in Wartime,

London and New York, Abingdon, Oxon pp 43-58

Keeble, Richard (2007) The necessary spectacular “victories”: New Militarism, the mainstream media and the manufacture of the Two Gulf Conflicts 1991 and 2003, Maltby, Sarah and Keeble, Richard (eds) Communicating War: Memory, Media and Military, Bury St Edmunds, Arima pp 200-212

Kemp, Anthony (1995) The SAS: Savage Wars of Peace, London, Signet Kemp, Col. Richard and Hughes, Chris (2009) Attack State: Taking the fight to the enemy. The awesome untold story of a landmark tour of duty in Afghanistan, London and New York, Michael Joseph 
Khan, Sartaj and Prasad, Yuri (2010) Crisis and conflict in Pakistan, International Socialism, Vol. 126, 14 April. Available online at

http://www.isj.org.uk/index.php4?id=636\&issue=126, accessed on 12 May 2010

Kirkup, James (2010) Kandahar offensive to target 1,000 Taliban, Daily Telegraph, 2

June

Lamb, Christina (2010) Battle for town is small step on the path to victory, Sunday

Times, 14 February

Larcombe, Duncan (2010) Mud 'guts, the Sun, 15 February

Leith, Sam (2010) The secret war on terror sets a bad example, Evening Standard, 7

June

MacAskill, Ewen (2010) US sends more soldiers on covert mission, Guardian, 26

May

McAskill, Ewen, Nasaw, Daniel and Boone, Jon (2010) CIA agents in Afghanistan

are "menace to themselves", former operatives claim, Guardian, 6 January

Martin, Patrick (2010) US military noose tightens on Afghanistan town, 12 February.

Available online at http://www.wsws.org/articles/2010/feb2010/afgh-f12.shtml, accessed on 13 February 2010

McKenzie, John (1984) Propaganda and Empire: The Manipulation of British Public Opinion 1880-1960, Manchester, Manchester University Press

Mellen, Tom (2010) Afghans “not ready to fight yet”, Morning Star, 8-9 May

Milne, Seamus (2009) In a war for democracy, why worry about public opinion,

Guardian, 15 October

Milmo, Cahal (2010) Forces of Facebook turn on the Daily Mirror, Independent, 19

March

Moore, Robin (2003) Taskforce Dagger: The Hunt for Bin Laden, New York, Random House

Morris, Nigel (2010) Afghan war is unwinnable and we should pull it now, say voters, Independent, 21 April

Morning Star (nb) (2010) Pakistani military gets 17\% boost to spending, 7 June

Newsinger, John (1995) The myth of the SAS, Lobster, Vol. 30 pp 32-36

Newton Dunn, Tom (2010) Troops to get trauma help, Sun, 7 June

Norton-Talor, Richard (2010a) British troops may leave Helmand as tension grows

over Afghan role, Guardian, 22 April

Norton-Taylor, Richard (2010b) Cost of war in Afghanistan soars to £2.5bn,

Guardian, 13 February

Norton-Taylor, Richard (2010c) Afghan police failings fuelling Taliban, say UK army

chiefs, Guardian, 4 June

Norton-Taylor, Richard (2010d) Four more years of Afghan war, warns Nato official,

Guardian, 30 April 
Norton-Taylor, Richard (2010e) Afghan private security firms ‘fuelling corruption’, Guardian, 14 May

Peak, Steve (1982) Britain’s military adventures, The Pacifist, Vol. 20 p 10

Pilger, John (2003) What good friends left behind, Guardian Weekend, 20 September pp 43-49

Pilger, John (2010) A predatory ideology in denial, Morning Star, 27-28 March pp $10-11$

Porter, Gareth (2010a) Night raids belie McChrystal’s new image, Asia Times, 2 April. Available online at inthesetimes.com/2010/04/03/night-raids-belie-mcchrystalsnew-image/\#more-11017

Porter, Gareth (2010b) Marja, the city that never was, the Coldtype Reader p 8-9. Available online at http://www.coldtype.net/Assets.10/Pdfs/0410.Reader45.pdf, accessed on 22 May 2010

Ray, Ellen and Schaap, William H. (1991) Disinformation and covert action, Covert Action Information Bulletin, No. 37, summer pp 9-13

Rayment, Sean (2010) The hidden victims of war: 1,000 casualties of the Afghan conflict, Sunday Telegraph, 21 February

Rose, Stephen (1986) Spend, spend, spend - on military only, New Statesman, 3 January

Scott, Jake (2008) Blood Clot: In combat with the Patrols Platoon, 3 Para, Afghanistan, 2006, Solihull, Helion and Company Sengupta, Kim (2010a) US cruise missile parts found in Yemeni village where 52 died, Independent, 7 June

Sengupta, Kim (2010b) Army given new rifles to engage enemies from further away, Independent, 7 June 
Sengupta, Kim (2010c) British military split over plan to move troops to Kandahar, Independent, 27 April

Sengupta, Kim (2010d) UN asks drone attacks to be taken out of CIA’s hands, Independent, 3 June 2010

Senguta, Kim (2010e) Warning to politicians about early Afghan troop pull-out, Independent, 28 May

Sengupta, Kim and Morris, Nigel (2010) Afghan war is bad for security, voters say, Independent, 11 November 2009

Shah, Saeed (2010) Taliban arrests in Pakistan amid talk of policy shift, Guardian, 19

February

Stiglitz, Joseph and Bilmes, Linda (2009) The three trillion dollar war, London, Penguin

Sturcke, James (2008) SAS commander quits in Snatch Land Rover row, Guardian, 1 November. Available online at http://www.guardian.co.uk/uk/2008/nov/01/sascommander-quits-afghanistan, accessed on 1 May 2009

Swanson, David (2010) Afghan escalation funding, 11 May. Available online at http://www.tomdispatch.com/blog/175246/tomgram\%3A_david_swanson,_did_you_s ay_\$33_billion_/, accessed on 12 May 2010

Taylor, Matthew (2009) Kidnapped Guardian journalist released, Guardian, 17

December

Turse, Nick (2008) The trillion dollar tag sale, 26 October. Available online at http://www.nickturse.com/articles/tom_trillion.html, accessed on 1 May 2009 Turse, Nick (2010) The 700 military bases of Afghanistan, 9 February. Available online at 
http://www.tomdispatch.com/blog/175204/tomgram:_nick_turse,_america's_shadowy _base_world/, accessed on 10 February 2010

Turse, Nick and Engelhardt, Tom (2010) Shooting gnats with a machine, 14 January. Available online at www.tomdispatch.com/dialogs/print/?id=175191

Walsh, David (2010) US military's private spy and murder ring continues to operate in Afghanistan, Pakistan, 18 May. Available online at www.wsws.org/articles/2010/may2010/cont-m18.shtml, accessed on 20 May 2010 Walsh, Declan (2010a) Taliban leaderin Pakistan survived CIA drone strike said to have killed him, spy agency says, Guardian, 29 April

Walsh, Declan (2010b) US hails ‘big victory’ after Islamist website confirms drone strike killed al-Qaida veteran, Guardian, 2 June

Waught, Rob (2010) The rise of the robo-fighters, Daily Mail, 5 May

Willetts, David (2010) A wing and a prayer, Sun, 7 June

Wintour, Patrick and Norton-Taylor, Richard (2010) Commanders fearTaliban

infiltration as troops hunt assassin, Guardian, 11 May

\section{Websites}

http://afpak.foreignpolicy.com/ - critical readings on Afghanistan and Pakistan www.anandgopal.com - site of distinguished journalist specialising in Afghanistan http://www.afghanistannewscenter.com/ - excellent round up of news from a range of sources (e.g. BBC, Xinhua news agency, Press Trust of India, McClatchy Newspapers, Guardian) www.theatlanticwire.com - US-based site with useful range of features on Afghanistan www.juancole.com - invaluable Informed Comment blog http://rethinkafghanistan.com/blog/ - progressive US commentaries on Afghanistan www.stephengrey.com - distinguished freelance, investigative reporter specialising in "war on terror" and Guantanamo Bay www.warincontext.org- commentary by Paul Woodward particularly useful 